\title{
Fracture Resistance of Weakened Roots Restored with Composite Resin and Glass Fiber Post
}

\author{
Lucas Villaça ZOGHEIB ${ }^{1}$ \\ Jefferson Ricardo PEREIRA ${ }^{2}$ \\ Accácio Lins do VALLE ${ }^{3}$ \\ Jonas Alves de OLIVEIRA ${ }^{4}$ \\ Luiz Fernando PEGORARO ${ }^{3}$ \\ ${ }^{1}$ Department of Prosthodontics, Dental School of São José dos Campos, \\ State University of São Paulo, São Jose dos Campos, SP, Brazil \\ ${ }^{2}$ Department of Prosthodontics, Dental School, University of Southern Santa Catarina, Tubarão, SC, Brazil \\ ${ }^{3}$ Department of Prosthodontics, Dental School of Bauru, University of São Paulo, Bauru, SP, Brazil \\ ${ }^{4}$ Department of Prosthodontics, Amazonas State University, Manaus, AM, Brazil
}

\begin{abstract}
This study evaluated the fracture resistance of weakened roots restored with glass fiber posts, composite resin cores and complete metal crowns. Thirty maxillary canines were randomly divided into 3 groups of 10 teeth each: teeth without weakened roots (control); teeth with partially weakened roots (PWR) and teeth with and largely weakened roots (LWR). The control group was restored with glass fiber posts and a composite resin core. Teeth in the PWR and LWR groups were flared internally to standardized dimensions in order to simulate root weakness. Thereafter, the roots were partially filled with composite resin and restored in the same way as in the control group. The specimens were exposed to 250,000 cycles in a controlled chewing simulator. All intact specimens were subjected to a static load $(\mathrm{N})$ in a universal testing machine at 45 degrees to the long axis of the tooth until failure. Data were analyzed by one-way ANOVA and Dunnett's test for multiple comparisons $(p=0.05)$. There were statistically significant difference differences $(p<0.01)$ among the groups (control group $=566.73 \mathrm{~N} ; \mathrm{PWR}=409.64 \mathrm{~N}$; and LWR $=410.91 \mathrm{~N}$ ), with significantly higher fracture strength for the control group. There was no statistically significant difference $(\mathrm{p}>0.05)$ between the weakened groups. The results of this study showed that thicker root dentin walls significantly increase the fracture resistance of endodontically treated teeth.
\end{abstract}

Key Words: post-and-core technique, composite resins, fracture strength.

\section{INTRODUCTION}

Endodontically treated teeth with flared roots or weakened root walls present a challenge to restorative dentistry. The extensive structural damage of the root can sometimes be as a result of immature development, dental caries, over-instrumentation, previous restoration with an excessively large dowel and core, fractures or internal resorption (1-3). The residual structure that remains is a thin root wall that makes the restorative procedure more difficult and can compromise the prognosis for a long-term successful restoration of the tooth (1-4). Furthermore, tooth strength is directly related to the bulk of the dentin tissue surrounding the post (5).
Some authors (6-8) have advocated that two factors determine if a post is necessary or not to restore compromised endodontically treated teeth: the amount of dentin remaining to retain the core and the nature of internal root structure. Several materials have been used to fill radicular defects with the aim of increasing the resistance of the weakened roots, such as glass ionomer cements, composite resins and hybrids of glass ionomers cement and composite resin $(1-4,9,10)$.

Various techniques have been recommended and described in the literature $(4,9-11)$ in order to reinforce weakened endodontically treated teeth. The results of fracture resistance of endodontically treated teeth restored by cast posts or prefabricated posts found in 
the literature were acceptable clinically because they are considerably higher than the maximal physiologic forces acting on teeth in the oral cavity (12-14). However, Asmussen et al. (15) have suggested that mechanical properties of post systems should be considered when investigating the causes of failure in endodontically treated crowned teeth. The restoration of root-filled teeth with metal-free material having physical properties similar to those of dentin has been suggested in restorative dentistry (16-17). Christensen (18)reported that physical properties of post systems become more important as residual intact tooth structure decreased. Manocci et al. (19) investigated the intermittent loading response of teeth restored with quartz-fiber, carbon quartz fiber, and zirconium posts and concluded that the fiber posts were able to reduce the risk of root fractures. A recent study (20) has shown that groups restored with carbon fiber post-and-composite resin core presented coronal structure or composite resin core failure before root fracture occurred.

The purpose of this study was to evaluate the fracture resistance of endodontically treated teeth with three different thicknesses of cervical dentin restored with glass fiber posts, composite resin cores and complete metal crowns. The tested null hypothesis was that there is a significant difference in the effect of thickness of cervical dentin on the fracture resistance.

\section{MATERIAL AND METHODS}

\section{Tooth Selection}

Thirty sound maxillary canines of similar root lengths were selected for this study. Each tooth was examined under a microscope to ensure the absence of carious lesions, cracks and microfractures. Selected teeth were stored in saline at $37^{\circ} \mathrm{C}$ during the course of the experiment. Tooth crowns were reduced perpendicular to the root axis with double-faced diamonds discs (KG Sorensen, Barueri, SP, Brazil), leaving a standardized root length of $14 \mathrm{~mm}$.

\section{Endodontic Treatment}

Root canals were prepared with K-files (Maillefer, Ballaigues, Switzerland) according to a conventional step-back technique up to a size 40 file. After intermittent rising with $2.5 \%$ sodium hypochlorite solu- tion (Asfer Industrial Química, São Paulo, SP, Brazil), the canals were dried with paper points (Tanari; Tanariman Industrial Ltda, Macaçaruru, AM, Brazil) and obturated with gutta-percha cones (Tanari; Tanariman Industrial Ltda.) and Sealer 26 eugenol-free sealer (Dentsply Ind. e Com. Ltda., Petrópolis, RJ, Brazil). The master gutta-percha cone was coated with sealer and seated in the canal to the full working length. Lateral condensation with fine gutta-percha points (Tanari; Tanariman Industrial Ltda.) was performed until the entire canal was obturated. Two weeks after root canal treatment, $9 \mathrm{~mm}$ of gutta-percha was removed with a Largo bur (size 5 reamer) (Dentsply Maillefer).

\section{Control and Experimental Groups}

The teeth were randomly assigned to three groups of 10 teeth each: control group, PWR (partial weakened roots) group and LWR (largely weakened roots) group (Fig. 1). In the control group, after canal preparation with a Largo bur (size 5 reamer) (Dentsply Maillefer), each tooth was restored with a glass fiber prefabricated post (diameter $1.5 \mathrm{~mm}$ and length $15 \mathrm{~mm}$, number 3) (Reforpost; Angelus, Londrina, PR, Brazil) and composite resin (Z250; 3M/ESPE, St. Paul, MN, USA) core. The size and shape used to the composite resin cores were standardized using a core-forming matrix (TDV Dental; Pomerode, SC, Brazil). All test specimens were cemented with dual-polymerizing adhesive resin luting agent (Rely X ARC; 3M/ESPE). The cement mix was prepared according to the manufacturer's instructions and introduced into each root canal with a lentulo spiral drill (Dentsply Maillefer) on a low-speed handpiece. Cement was placed on the post and seated under a static load of $5 \mathrm{~kg}$ for $10 \mathrm{~min}$ with a cementing

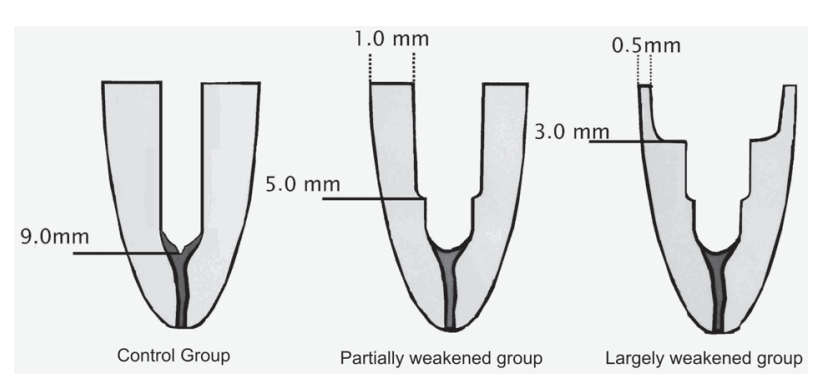

Figure 1. Diagram of the three study protocols. 
device. Excess cement was removed. After that, the dentin was etched with $37 \%$ phosphoric acid and a bonding agent (Scotchbond Multipurpose Plus; 3M/ ESPE) was applied to the dentin as recommended by the manufacturer. Cores were fabricated with composite resin (Z250; 3M/ESPE) according to an incremental technique. Each layer had approximately $1.5 \mathrm{~mm}$ in thickness, as measured with a periodontal probe, and was polymerized for $40 \mathrm{~s}$ until a complete coronal core. was obtained. A light-curing unit (Ultraled, Dabi Atlante, Ribeirão Preto, SP, Brazil) with intensity of $450 \mathrm{~mW} /$ $\mathrm{cm}^{2}$ was used for composite resin photoactivation. The tip of the curing light was located $2 \mathrm{~cm}$ from the specimens on top of the core.

In the PWR group, a spherical diamond bur (\#1016; KG Sorensen) was initially used at high-speed to flare the root canal to a depth of $9 \mathrm{~mm}$, and another spherical diamond bur (\#3017 HL; KG Sorensen) was used for middle third flaring, reaching a depth of $5 \mathrm{~mm}$, and leaving the remaining dentin walls with a thickness of $1 \mathrm{~mm}$. The LWR group differed from the PWR group due to an additional wear in the cervical third of the canal prepared with a spherical diamond bur (\#3018 HL; KG Sorensen) to a depth of $3 \mathrm{~mm}$, leaving the remaining dentin walls with $0.5 \mathrm{~mm}$ thickness.

\section{Restoration of the Roots}

The specimens of the PWR group and LWR group had the cervical and middle third of the root canal reinforced by light-cured composite resin (Z250; 3M/ ESPE) using a translucent curing post (Luminex System; Dentatus Ltd., New York, NY, USA). Root dentinal walls were etched with $37 \%$ phosphoric acid for $15 \mathrm{~s}$. Abundant rinsing with water and drying with paper points (Tanari; Tanariman Industrial Ltda.) was performed. Thereafter, the bonding agent (Scotchbond Multipurpose Plus, 3M/ESPE) was placed on the dentin as recommended by the manufacturer. The translucent post was used in the canal during bonding agent polymerization and was used during root filling with the composite resin, which was inserted in layers around the post using a resin spatula. Each layer was approximately $1.5 \mathrm{~mm}$ thick (as measured with periodontal probe) and was polymerized for $40 \mathrm{~s}$ using same curing light used for core reconstruction. Cementation and core reconstruction procedures were done in the same was described for the control group.

\section{Metal Crowns}

Each tooth was prepared with a \#3216 diamond bur (KG Sorensen) under water spray to receive a complete metal crown using. The facial and lingual surface were prepared with a uniform reduction. The $1.5 \mathrm{~mm}$ chamfered facial line and $0.5 \mathrm{~mm}$ chamfered lingual line were prepared at the level of the cementoenamel junction. The gingivoincisal dimension was $4 \mathrm{~mm}$ for all preparations. The dimensions of the prepared cores were confirmed with a measuring microscope (Mitutoyo Co Ltd., Tokyo, Japan).

Impressions of the prepared specimens were taken with vinyl polysiloxane impression material (Aquasil; Dentsply, Konstanz, Germany) and complete metal crowns were fabricated by a skilled technician using a Ni-Cr alloy (Durabond; São Paulo, SP, Brazil). The standardized form of the crowns was confirmed with the initial silicone index made before tooth preparation. Dual-cure adhesive luting agent (Rely X ARC; $3 \mathrm{M} / \mathrm{ESPE}$ ) was used to cement these crowns.

\section{Mechanical Fatigue and Static Load}

Each tooth was embedded along their long axis using a surveyor (Bio Art Equipamentos Odontológicos Ltda., São Carlos, SP, Brazil) in acrylic blocks (30 mm in height and diameter of $22 \mathrm{~mm}$ ), in such a way that 2 $\mathrm{mm}$ of natural root structure was exposed and thinly covered (approximately $60 \mathrm{~mm}$ ) with a silicone impression material (Aquasil; Dentsply) to simulate a periodontal ligament (13).

All specimens in each group were exposed to 250,000 cycles of mechanical fatigue in a controlled chewing simulator. The force was applied $3 \mathrm{~mm}$ below the incisal edge on the palatal surface of the crowns at a frequency of $2.6 \mathrm{~Hz}$. A force of $30 \mathrm{~N}$ was chosen. The number of specimens still intact after the fatigue loading was recorded and expressed as survival in percent.

Each intact specimen was positioned in the mounting device and aligned at a 45-degree angle with respect to the long axis of the tooth. A universal testing machine (Kratus K2000 MP; Dinamômetros Kratos Ltda, São Paulo, SP, Brazil) was used to apply a constant load at a crosshead speed of $0.5 \mathrm{~mm} / \mathrm{min}$ until failure occurred. The load was measured in Newtons (N). Failure was defined as the point at which the loading force reached a maximum value by fracturing 
the root or core, bending the post, or debonding the cement. After loading, the mode of failure was observed and analyzed with a $\times 4$ binocular lens (Bio Art Equipamentos Odontológicos Ltda.).

Data were analyzed statistically by one-way ANOVA and Dunnett's test at 5\% significance level.

\section{RESULTS}

All specimens survived the 250,000 cycles of intermittent loading. The following mean failure load values and standard deviation were obtained: control $=$ $566.7 \pm 149.4$; PWR: $409.6 \pm 94.8$; LWR: $410.9 \pm$ 133.5. The control group presented significantly higher $(p<0.01)$ fracture strength than the weakened groups, which in turn did not differ significantly from each other $(\mathrm{p}>0.05)$.

Differences regarding the mode of failure among the groups were observed and analyzed with a $\times 4$ binocular loop (Bio Art Equipamentos Odontológicos). In the control groups, the fractures generally involved the incisal third of the root, while the weakened groups generally involved the medium third of the root. The fracture patterns of all groups are presented in Figure 2.

\section{DISCUSSION}

The present study accepted the hypothesis that there is a significant difference in the fracture resistance of weakened roots restored with composite resin and glass fiber posts submitted by intermittent loading.

Results of the present investigation showed that none of the specimen failures occurred during exposure

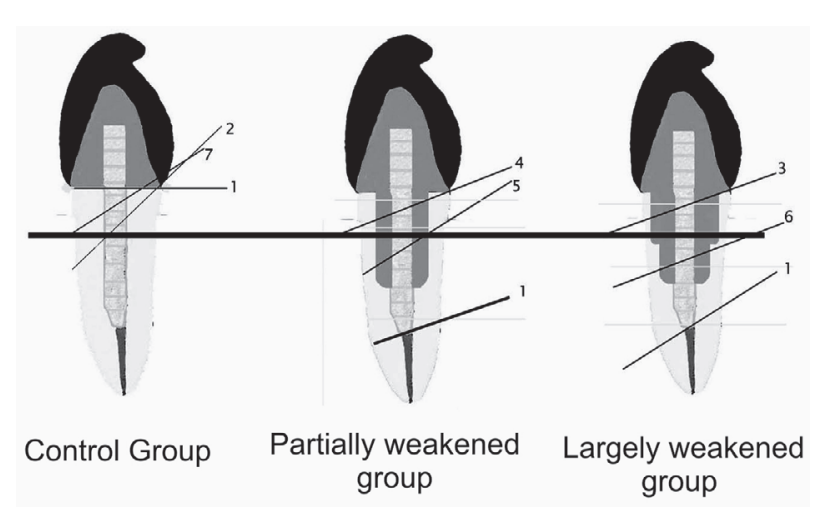

Figure 2. Fracture patterns observed in the three groups ( 1 to 7 indicates the number of specimens with each type of fracture). in intermittent loading tests. This could be because differences in the elastic modules of posts and dentin are minimal (19). This is in accordance with Dietschi et al. (16) and Isidor et al. (17) that suggested that a post should have the same modulus of elasticity as root dentin to distribute forces along the length of the post.

After static loading, the present study showed that there is a significant difference in the effect of different thickness of cervical dentin on the fracture resistance of endodontically treated teeth. This is because of greater dentin wall thickness around the prefabricated post, demonstrating that the resistance to fracture of endodontically treated teeth is directly proportional to the amount of remaining dentin structure $(5,11)$. The findings of the present study are in agreement with those of Tjan et al. (11), who found that canals with $1 \mathrm{~mm}$ of remaining buccal dentin walls were apparently more prone to fracture than those that had 2 and $3 \mathrm{~mm}$ of dentin walls.

The results of this study demonstrate that in cases of severely weakened roots, with very thin dentin walls, the use of composite resin associated to a glassfiber post does not rebuild the roots to the same levels of fracture resistance as the non-weakened roots. This is in agreement with the findings of Marchi et al. (10), who showed that root reinforcement does not recover the full resistance to fracture of roots. However, the findings of previous studies $(4,9)$ and those of the present investigation suggest that reinforcement of weakened roots may actually be a viable choice to reduce fracture ocurrence. This can be suggested based on the study of Lyons and Baxendale (12), which showed that the maximal physiological forces acting on the canine in the oral cavity was $215 \mathrm{~N}$ while the maximal force under parafunctional loading raised to $254.8 \mathrm{~N}$. These forces are lower than the minimal forces found in the present study, which suggests that the physiological forces could not cause the failure of the tooth.

The most common cause of failure of nonweakened roots (control group) was the fracture of the restorative material and cervical dentin ( 9 specimens), while the most common cause of failure of the weakened roots was the fracture of the root (6 specimens in PWR group and 7 specimens in LWR group). These outcomes are in accordance with those of previous studies $(1,5)$, which suggested that the strength of a tooth is directly related to the amount of the dentin tissue surrounding 
the post. Hence, the preservation of the tooth seems to protect the tooth structure.

In conclusion, the results of this study showed that thicker root dentin walls do significantly increase the fracture resistance of endodontically treated teeth. A limitation of this study is the fact that it was performed in vitro and the results should not be directly extrapolated to the clinical situation. For more meaningful results, further studies should incorporate thermocycling. Clinical trials are necessary to validate the results of the present in vitro study.

\section{RESUMO}

Este estudo avaliou a resistência à fratura de raízes fragilizadas restauradas com pinos de fibra de vidro, núcleos de resina composta e coroas totais metálicas. Trinta caninos superiores foram aleatoriamente divididos em 3 grupos. Dentes sem enfraquecimento (grupo controle); grupo de raízes parcialmente enfraquecidas e amplamente enfraquecidas. $\mathrm{O}$ grupo controle foi restaurado com pinos de fibra de vidro e núcleo em resina composta. Os dentes dos grupos de raízes parcialmente e amplamente enfraquecidas foram internamente preparadas de maneira padronizada simulando enfraquecimento. Após isto, as raízes foram parcialmente preenchidas com resina composta e restauradas como no grupo controle. Os espécimes foram expostos a 250.000 ciclos em uma máquina de ciclagem mecânica. Todos os dentes intactos foram submetidos à carga estática $(\mathrm{N})$ em uma máquina de ensaio universal a 45 graus ao longo eixo do dente até a sua falha. Os resultados foram analisados através do teste ANOVA a 1 critério e teste de Dunnett para comparações múltiplas $(p=0,05)$. A análise estatística revelou diferenças significantes $(\mathrm{p}<0,01)$ entre os três grupos (grupo controle $=$ $566,73 \mathrm{~N}$; RPE $=409,64 \mathrm{~N}$; e ERA $=410,91 \mathrm{~N})$. Quando as três médias de resistência a fratura são ranqueadas as duas menores não se diferem. Os resultados deste estudo mostraram que uma maior espessura de paredes dentinárias aumenta significantemente a resistência à fratura de dentes tratados endodonticamente.

\section{REFERENCES}

1. Lui JL. A technique to reinforce weakened roots with post canals. Endod Dent Traumatol 1987;3:310-314.

2. Lui JL. Cermet reinforcement of flared canals using light-transmitting plastic-posts. Quintessence 1992;23:533-538.

3. Lui JL. Composite resin reinforcement of flared canals using light-transmitting plastic post. Quintessence Int 1994;25:313319.

4. Mendonza DB, Eakle S, Kahl EA, Ho R. Root reinforcement with resin-bonded preformed post. J Prosthet Dent 1997;78:10-15.

5. Trabert KC, Caputo AA, Abou-Rass M. Tooth fracture- a comparison of endodontic and restorative treatments. J Endod 1978;4:341-345.

6. Christensen GJ. Posts and cores: state of the art. J Am Dent Assoc 1998;129:96-97.

7. Morgano SM. Restoration of pulpless teeth: application of traditional principles in present and future contexts. J Prosthet Dent 1996;75:375-380.

8. Chalifoux PR. Esthetic restoration of endodontically treated teeth: factors that affect prognosis. J Esthet Dent 1998; 10:75-83.

9. Saupe WA, Gluskin AH, Radke RA. A comparative study of fracture resistance between morphlogic dowel and cores and resin-reinforced dowel system in the intraradicular restoration of structurally compromised roots. Quintessence Int 1996;27:483491.

10. Marchi GM, Paulillo LAMS, Pimenta LAF, Lima FAP. Effect of different filling materials in combination with intraradicular posts on the resistance to fracture of weakened roots. J Oral Rehabil 2003;30:623-629.

11. Tjan AHL, Whang SB. Resistance to root fracture of dowel channels with various thicknesses of buccal dentin walls. J Prosthet Dent 1985;53:496-500.

12. Lyons MF. A preliminary electromyographic study of bite force and jaw-closing muscle fatigue in human subjects with advanced tooth wear. J Oral Rehabil 1990;17:311-318.

13. Pereira JR, de Ornelas F, Conti PC, do Valle AL. Effect of a crown ferrule on the resistance of endodontically treated teeth restored with prefabricated posts. J Prosthet Dent 2006;95:50-54.

14. Pereira JR, Mendonça Neto T, Porto V de C, Pegoraro LF, Valle $\mathrm{AL}$. Influence of the remaining coronal structure on the resistance of teeth with intraradicular retainer. Braz Dent J 2005;16:197201.

15. Asmussen E, Peutzfeldt A, Heitmann T. Stiffness, elastic limit and strength of newer types of endodontic post. J Dent 1999;27:275-278.

16. Dietschi D, Romelli M, Goretti A. Adaptation of adhesive posts and cores to dentin after fatigue testing. Int $\mathrm{J}$ Prosthodont 1997; 10:498-507.

17. Isidor $\mathrm{F}$, Ödman $\mathrm{P}$, Brøndum $\mathrm{K}$. Intermittent loading of teeth restored using prefabricated carbon fiber post. Int J Prosthodont 1996;9:131-136.

18. Christensen GJ. When to use fillers, build-ups or post and cores. J Am Dent Assoc 1996;127:1397-1398.

19. Mannocci F, Ferrari M, Watson T. Intermittent loading of teeth restored using quartz fiber, carbon-quartz fiber and zirconium dioxide ceramic root canal posts. J Adhes Dent 1999;1:153-158.

20. Oliveira JA, Pereira JR, Valle AL, Zogheib LV. Fracture resistance of endodontically treated teeth with different heights of crown ferrule restored with prefabricated carbon fiber post and composite resin core by intermittent loading. Oral Surg Oral Med Oral Pathol Oral Radiol Endod 2008;106:52-57. 